\title{
Effects of Cattle Grazing and Haying on Wildlife Conservation at National Wildlife Refuges in the United States
}

\author{
BEVERLY I. STRASSMANN \\ Museum of Zoology \\ University of Michigan \\ Ann Arbor, Michigan 48109, USA
}

\begin{abstract}
The National Wildlife Refuge System is perhaps the most important system of federal lands for protecting wildlife in the United States. Only at refuges has wildlife conservation been legislated to have higher priority than either recreational or commercial activities. Presently, private ranchers and farmers graze cattle on 981,954 ha and harvest hay on 12,021 ha at 123 National Wildlife Refuges. US Fish and Wildlife Service policy is to permit these uses primarily when needed to benefit refuge wild life. To evaluate the success of this policy, I surveyed grassland management practices at the 123 refuges. The survey results indicate that in fiscal year 1980 there were 374,849 animal unit months
\end{abstract}

(AUMs) of cattle grazing, or $41 \%$ more than was reported by the Fish and Wildlife Service. According to managers' opinions, 86 species of wildlife are positively affected and 82 are negatively affected by refuge cattle grazing or haying. However, quantitative field studies of the effect of cattle grazing and haying on wildlife coupled with the survey data on how refuge programs are implemented suggest that these activities are impeding the goal of wildife conservation. Particular management problems uncovered by the survey include overgrazing of riparian habitats, wild life mortality due to collisions with cattle fences, and mowing of migratory bird habitat during the breeding season. Managers reported that they spend $\$ 919,740$ administering cattle grazing and haying; thus refuge grazing and haying programs are also expensive. At any single refuge these uses occupy up to $50 \%$ of refuge funds and $55 \%$ of staff time. In light of these results, prescribed burning may be a better wild life management option than is either cattle grazing or haying
National Wildlife Refuges (NWRs), administered by the US Fish and Wildlife Service, are the only federal lands in the United States where wildlife conservation has higher priority than either recreational or commercial activities. The major statute regulating their use is the National Wildlife Refuge System Administration Act (1966, as amended 16 USC 668). Pursuant to this act, no commercial or recreational uses of refuges may be permitted unless the Secretary of the Interior has determined that they are compatible with the primary purposes for which refuges are established. By federal law [50 CFR 25.11(b)], all NWRs are "maintained for the primary purpose of developing a national program of wildlife and ecological conservation and rehabilitation."

Although wildlife conservation has legal priority at NWRs, the public enjoys access to refuges for various recreational opportunities including hunting, waterskiing, and off-road vehicle use (Table 1). Paid permits give private individuals and companies access to refuge land for such commercial purposes as: lumbering, mining, trapping, oil and gas development, crop production, and cattle grazing (Table 1).

This review focuses on two commercial uses of refuges: cattle grazing and haying. According to Fish

KEY WORDS: Refuges; Widdife conservation; Rangeland, federal; Livestock; Grazing; Haying and Wildlife Service (FWS) policy (FWS 1982), cattle grazing and haying are employed primarily as "wildlife management tools." Annually, the FWS reports the extent of cattle grazing and haying at particular refuges (for example, FWS 1980a), but does not assess the compatibility of these activities with wildlife conservation. Several recent reports underscore the importance of ecological assessments of these activities. Smith (1977) and Platts (1978) concluded that livestock grazing is the single most important factor limiting wildlife production in the West. Two reviews of the management of the NWR system reported that grazing and haying can be abusive and called for a reevaluation of these activities (Braun and others 1978, NWR Task Force 1979). In response to a court order in Natural Resources Defense Council, Inc., et al. v. Morton et al., three refuges prepared environmental impact statements (EISs) indicating that refuge cattle grazing severely harms wildlife, and recommending either elimination of cattle or drastic reductions in stocking (FWS 1980c, 1981, and 1984).

Despite these reports that grazing and haying may be harmful to wildlife, FWS Director Robert A. Jantzen has announced plans for increased grazing of refuges (Jantzen 1983). I report here the results of a refuge grassland management survey that was designed to determine whether refuge cattle-grazing and haying programs are compatible with wildlife conservation. 
Table 1. Recreational and commercial uses of National Wildlife Refuges (from Strassmann 1983).

\begin{tabular}{|c|c|c|c|}
\hline & \multicolumn{2}{|c|}{ Recreational uses } & \multirow[b]{2}{*}{$\begin{array}{c}\text { Commercial } \\
\text { uses }\end{array}$} \\
\hline & $\begin{array}{l}\text { No. visits } \\
\text { (thousands) }\end{array}$ & $\begin{array}{l}\text { Activity-hours } \\
\text { (thousands) }\end{array}$ & \\
\hline \multicolumn{4}{|l|}{ Wildlife (consumptive) } \\
\hline Hunting & 828 & 3.938 & \\
\hline Trapping & 104 & 342 & \\
\hline Fishing & 4,747 & 9,329 & \\
\hline Other & 981 & 2,405 & \\
\hline \multicolumn{4}{|l|}{ Wildlife (nonconsumptive) } \\
\hline Wildlife trails & 667 & 909 & \\
\hline Environmental education & 112 & 675 & \\
\hline Photography & 234 & 374 & \\
\hline Other & 10.440 & 20,070 & \\
\hline \multicolumn{4}{|l|}{ Nonwildlife } \\
\hline Waterskïng & 200 & 502 & \\
\hline Off-road vehicle use & 45 & 47 & \\
\hline Boating & 931 & 3,043 & \\
\hline Other & 5,031 & 17,475 & \\
\hline Timber harvests $\left(\mathrm{m}^{3}\right)$ & & & 38,273 \\
\hline Trapping of fur-bearers (pelts) & & & 146.259 \\
\hline Crop harvests (kg) & & & $354,594,371$ \\
\hline Cattle grazing (AUMs) & & & 370,926 \\
\hline Hay harvests (kg) & & & $39,706,646$ \\
\hline
\end{tabular}

Table 2. Total grazing and haying in the National Wildlife Refuge System (from Strassmann 1983).

\begin{tabular}{|c|c|c|c|}
\hline & $\begin{array}{l}\text { NWR } \\
\text { total }\end{array}$ & $\begin{array}{c}\text { Mean } \\
\text { per refuge }\end{array}$ & $\begin{array}{l}\text { Maximum } \\
\text { per refuge }\end{array}$ \\
\hline $\begin{array}{l}\text { AUMs of } \\
\text { grazing }\end{array}$ & 374,849 & 3,864 & 60,108 \\
\hline $\begin{array}{l}\text { Hectares } \\
\text { grazed }\end{array}$ & 981,954 & 10,968 & 363,525 \\
\hline $\begin{array}{l}\text { Metric tons } \\
\text { of hay } \\
\text { Hectares }\end{array}$ & 40,717 & 690 & 3,867 \\
\hline $\begin{array}{l}\text { Hectares } \\
\text { hayed } \\
\text { AUMs per }\end{array}$ & 12,021 & 207 & 1,129 \\
\hline $\begin{array}{l}\text { hectare } \\
\text { Metric tons } \\
\text { of hay per } \\
\text { hectare }\end{array}$ & - & 2.50 & 16.72 \\
\hline
\end{tabular}

\section{Methods}

A comprehensive questionnaire covering every major aspect of refuge grassland management, but emphasizing grazing and haying, was sent to each of the 123 refuges allowing these activities (Strassmann 1983). Before distribution, the questionnaire was reviewed by both Washington and field staff of the Department of the Interior. It was also reviewed by national conservation organizations, including Defenders of Wildlife, the organization that funded and sponsored the questionnaire. The Washington office of the FWS directed the FWS field personnel to respond and to send completed questionnaires to Defenders of Wildlife and to the FWS Washington office. The ques-

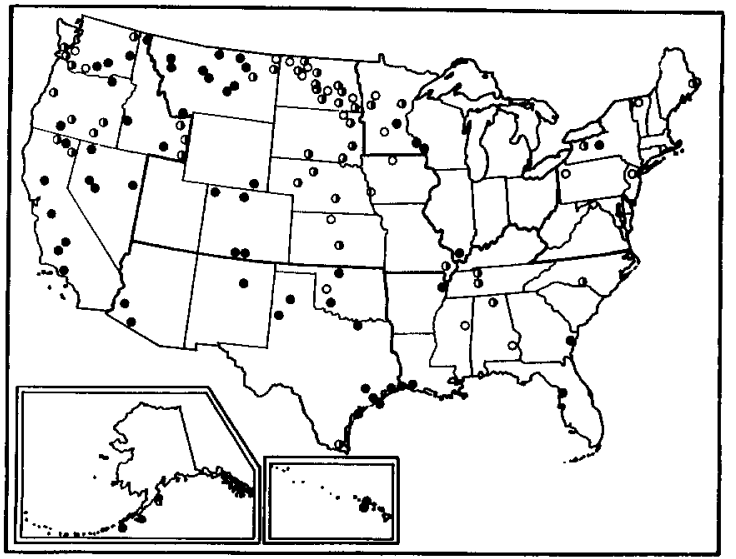

Figure 1. Locations of National Wildlife Refuges permitting either cattle grazing or haying: $\bullet$, refuges allowing grazing only; $\mathrm{O}$, refuges allowing haying only; and $\mathbf{O}$, refuges allowing both grazing and haying. From Strassmann (1983).

tionnaires may be examined at these locations, and individual responses may be found at each of the 123 refuges. Over $90 \%$ of the questionnaires were returned. I obtained the most important information from the remaining refuges through further correspondence and phone calls. .

In $1980 \mathrm{I}$ also made on-site inspections of cattlegrazing and haying programs at the following refuges: Clear Lake NWR, California; Delevan NWR, California; Kern NWR, California; Lower Klamath NWR, California; Modoc NWR, California; Valentine NWR, Nebraska; Sheldon NWR, Nevada; Hart Mt. NWR, Oregon; Malheur NWR, Oregon; Upper Klamath NWR, Oregon; Aransas NWR, Texas; Brazoria NWR, Texas; and San Bernard NWR, Texas.

\section{Results and Discussion}

\section{Total Grazing and Haying}

Livestock grazing is measured by the animal unit month (AUM), which is the amount of forage needed to maintain a $450-\mathrm{kg}$ cow for 30 days. The survey shows that in fiscal year 1980 there were 374,849 AUMs of cattle grazing on 981,954 ha at 104 National Wildlife Refuges (Table 2). Most of these refuges are west of the Mississippi River, but a few are in the Southeast and the Northeast (Figure 1). According to the FWS (FWS 1980a), there were only 266,590 AUMs of grazing on 663,603 ha. The large discrepancy is due to omissions of entire refuges in the FWS inventory. Throughout the NWR system, 40,717 metric tons of hay were harvested on 12,021 ha at 63 refuges (Figure 1). 
Table 3. Numbers of vertebrate species that, in the opinion of refuge managers, are positively or negatively affected by refuge grazing or haying programs (from Strassmann 1983).

\begin{tabular}{lcc}
\hline & $\begin{array}{c}\text { Number of species } \\
\text { positively affected }\end{array}$ & $\begin{array}{c}\text { Number of species } \\
\text { negatively affected }\end{array}$ \\
\hline Mammals (nonungulates) & 14 & 19 \\
Mamamals (ungulates) & 5 & 7 \\
Waterfowl & 16 & 13 \\
Shorebirds and wading birds & 14 & 9 \\
Raptors & 11 & 0 \\
Upland and woodland birds & 24 & 26 \\
Reptiles & 2 & 8 \\
All species & $86^{\mathrm{b}}$ & $82^{\mathrm{b}}$ \\
\hline
\end{tabular}

aThe total number of species reported $=139$.

b31 species were reported as both positively and negatively affected.

\section{Livestock Effects on Wildlife}

The questionnaires asked managers to list, according to habitat and season, the wildlife species they thought to be affected either positively or negatively by their grazing or haying programs and to cite any studies they relied on in providing this information. Managers were also asked to specify the type and intensity of grazing and mean annual precipitation at their refuges. Managers listed a total of 139 species: 86 as positively affected and 82 as negatively affected by grazing or haying (Table 3). Tables 4 and 5 list the species most commonly cited by managers.

The species in the tables reflect managers' opinions. The following discussion will compare their opinions to the results of quantitative field studies on the effect of grazing and haying on the same species. Due to space limitations I will restrict my analysis to the species that managers most commonly believed to benefit from grazing or haying (Table 4). It is important to note that the effects of grazing on wildlife differ depending upon local habitat characteristics. Hence it is difficult to provide quantitative generalizations on the effects of grazing on populations of the same species occurring in different habitats-particularly under different climatic conditions and grazing regimes. To address this problem, I attempted to locate studies that were conducted under conditions similar to those affecting the species in Table 4 at wildlife refuges. However, due to the paucity of controlled studies that quantify the effects of cattle grazing on wildlife, further research would be useful. I suggest that the species in Table 4 receive high priority for research funds.

Ungulates. Managers of four refuges believed
Table 4. Vertebrate species that managers of four or more refuges believe to be positively affected by refuge grazing or haying programs (from Strassmann 1983).

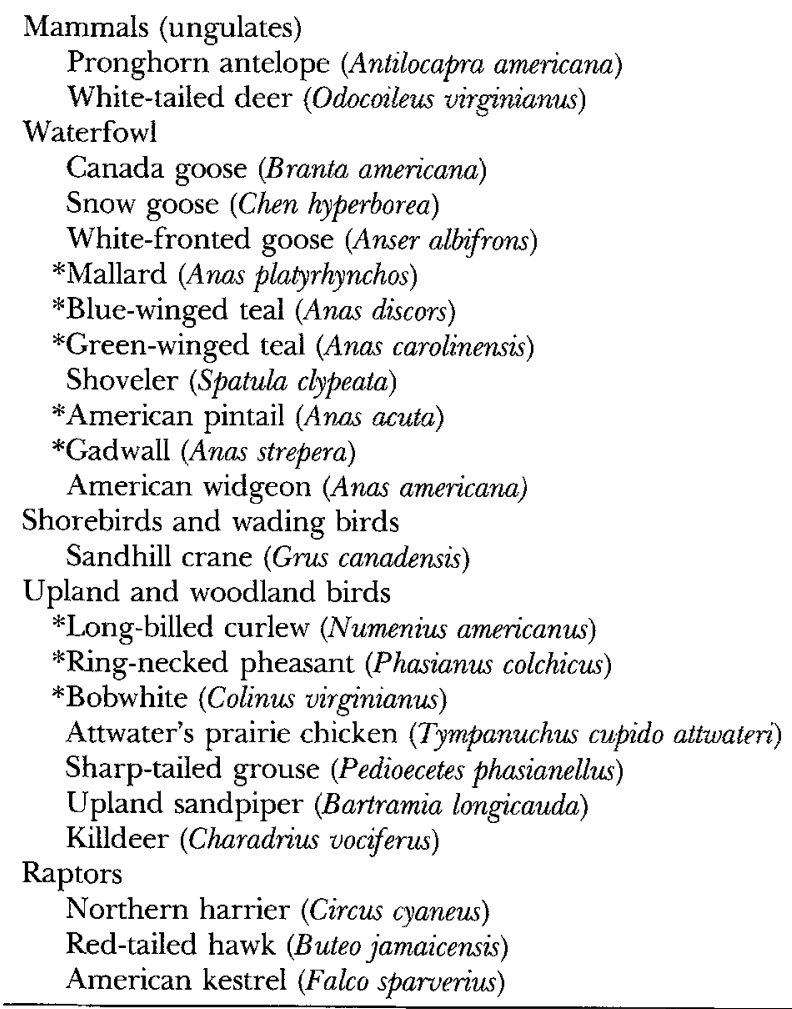

* Indicates species that managers of two or more other refuges reported to be negatively affected.

pronghorn antelope (Antilocapra americana) benefit from cattle grazing despite the following adverse effects of cattle: competition for annual forage (Wagner 1978), introduction of early successional vegetation at the expense of the climax communities preferred by pronghorns (Wagner 1978, Mackie 1978), depletion of the key browse plants of critical wintering areas (Mackie 1978, Wagner 1978), and reduction of fawn survival through the consumption and trampling of protective cover. At the Sheldon Refuge, Nevada, 72\% fewer fawns were born in part of the refuge when it was grazed by cattle than when cattle were excluded (McNay and O'Gara 1982).

Managers frequently thought that white-tailed deer (Odocoileus virginianus) benefit from grazing. Deer populations have increased following the cattle-induced spread of brushy vegetation into grassland areas (Wagner 1978), but cattle can exclude deer from available habitats and greatly reduce fawn survival (Mackie 1978). In an eight-year study in the Edwards Plateau, Texas, deer production decreased as stocking of 
Table 5. Vertebrate species that managers of two or more refuges believe to be negatively affected by refuge grazing or haying programs (from Strassmann 1983).

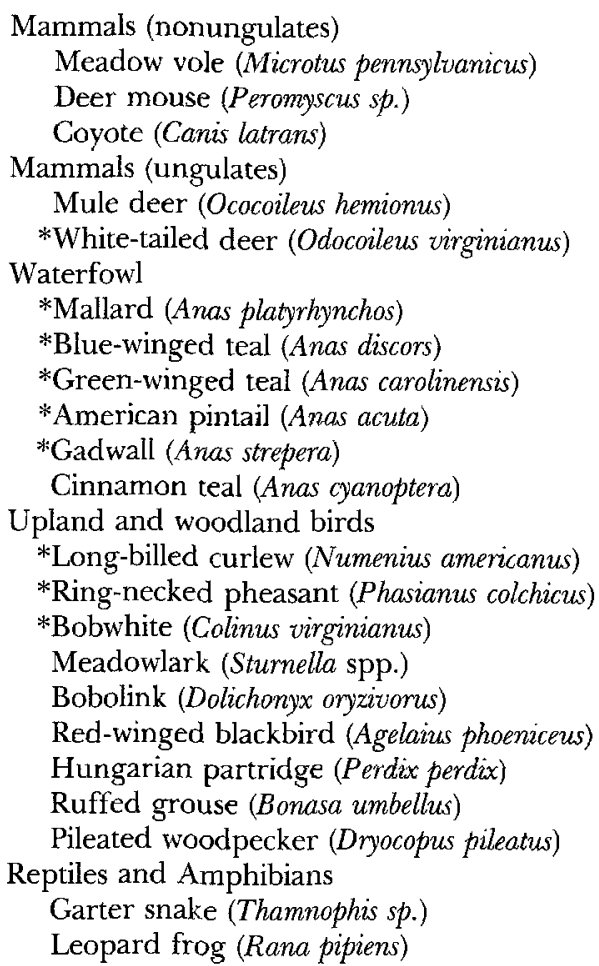

* Indicates species that managers of four or more other refuges reported to be positively affected.

sheep, goats, and cows increased. In a heavily grazed pasture, deer production was nil, while in a pasture without livestock the deer herd increased by an annual mean of 37\% (McMahan and Ramsey 1965).

Waterfowl. There is solid evidence that cattle grazing is harmful to all species of ducks that managers believed to benefit from grazing (CVWMA 1974). For example, Kirsch (1969) concluded: "In reviewing the literature I was unable to find a single example where grazing or other cover removal activities increased waterfowl production." The Conservation Committee of the Wilson Ornithological Society (Braun and others 1978) reported: "At least 55 waterfowl studies have shown that grazing is detrimental to waterfowl production." Studies of grazed and ungrazed plots demonstrate that grazing reduces nesting success and the likelihood of nesting attempts through the removal and trampling of residual cover (for example, Bue and others 1952, Weller and others 1958, Salyer 1962, Jahn and Hunt 1964, Capel 1965, Kirsch 1969, CVWMA 1974, Kirsch and others 1978). For ex- ample, cattle grazing at Malheur Refuge, Oregon, cuts duck production in half by reducing nesting cover (Clark 1977).

Holechek and others (1982), however, conclude that limited grazing or burning every $1-3$ years increases blue-winged teal (Anas discors) production in Iowa and South Dakota. At Union Slough NWR, Iowa, Burgess and others (1965) found that bluewinged teal have higher nesting success in moderately grazed areas than in ungrazed areas. However, the ungrazed areas in their study consisted of narrow strips or small "clumps" that were later shown to be more vulnerable to predation (Kirsch 1969).

Holechek and others and Burgess and others notwithstanding, most waterfowl are much more likely to be harmed than helped by cattle grazing in their nesting areas. But grazing of goose feeding areas can increase the abundance of edible green shoots (Greenwalt 1978). Prescribed burning can also increase browse and is sometimes considered preferable (see FWS 1980b).

Shorebirds and Wading birds. Managers commonly listed the sandhill crane (Grus canadensis) as benefiting from grazing or haying. At Bosque del Apache NWR, New Mexico, however, crane populations nearly tripled after the removal of cattle (Braun and others 1978). In a four-year study at Malheur NWR, Oregon, nesting success of sandhill cranes was $66.7 \%$ in idle fields, which was significantly greater than the success rate of $46.1 \%$ in grazed fields (Littlefield, pers. comm.).

Upland and Woodland Birds. Managers listed several gallinaceous birds-bobwhite quail, prairie chickens, ring-necked pheasants, and sharp-tailed grouse-as beneficiaries of grazing. The following results, however, suggest that grazing has the potential to adversely affect these species: nest densities for bobwhite quail (Colinus virginianus) about three times greater in idle fields than in grazed or hayed fields (Klimstra and Roseberry 1975), loss of residual cover in Attwater's prairie chicken (Tympanuchus cupido attwateri) habitat caused by annual grazing or haying (Kirsch 1974), adverse effects of grazing on ring-necked pheasants (Phasianus colchicus) because of loss of residual nesting cover (Kirsch and others 1978), and local extinction of sharp-tailed grouse (Pedioecetes phasianellus) populations due to grazing of residual cover and loss of essential shrubs in wintering habitat (Kessler and Bosch 1982). Kirsch (1974) reports that prairie chicken habitat is improved by prescribed burning at three fiveyear intervals (Kirsch 1974), while Holechek and others (1982) conclude that although overgrazing has 
limited prairie chicken populations more than undergrazing, carefully controlled grazing along with burning and mowing can be beneficial.

Managers commonly listed three additional species of upland birds as positively affected by grazinglong-billed curlews, killdeer, and upland sandpipers. Long-billed curlews (Numenius americanus) require short vegetation for breeding. Heavy cattle grazing prior to the nesting season, so that nests are not trampled, improves their habitat (Bicak and others 1982). Interspersion of some areas of ungrazed grassland also has been recommended for curlews (Brown 1978). Because killdeer (Charadrius vociferus) nest in short grass, they might benefit from grazing, haying, or prescribed burning outside the nesting season. Kirsch and Higgins (1976) found that grazing decreased the nesting success of upland sandpipers (Bartramia longicauda) below levels found in burned or undisturbed prairie. Specifically, the mean number of nests hatched per 40.5 ha was 0.5 in grazed grassland, 1.1 in undisturbed grassland, and 2.2 in grassland managed by prescribed burning.

Raptors. Little information exists either to support or to refute managers' contention that three species of raptors (northern harriers, red-tailed hawks, and American kestrels) benefit from cattle grazing, although Duebbert and Lokemoen (1977) found that northern harriers (Circus cyaneus) did not nest in grazed habitats. In a four-year study at Malheur Refuge, Oregon, northern harriers hunted significantly more in idle fields where densities of microtine prey were significantly higher than in mowed or mowed-grazed fields (Littlefield and others 1979, Littlefield personal communication).

The managers' belief that the species in Table 4 benefit from grazing or haying may have been encouraged by the once popular notion that "good range management is good wildlife management" (see Kessler and Bosch 1982). Contentions that game species benefit from grazing and that adverse effects on nongame species were unimportant used to be prevalent. According to former Director of the FWS, Lynn Greenwalt (Greenwalt 1978), this view has been displaced by more recent studies that have "clearly demonstrated that with rare exceptions, grazing is not consistent with optimum wildlife use of natural habitats." The review by Holechek and others, by contrast, emphasizes the potential positive effects of livestock grazing on wildlife under specialized circumstances. Their perspective perhaps derives from their implicit opposition to stocking reductions reflected in their assumption that "increases in both livestock and wildlife production will be necessary on both public and private rangeland in coming years...."

The managers' statements that the species in Table 4 benefit from grazing or haying may also stem from outdated management plans. Plans that were originally conceived in the 1950s and 1960s are still in use at many refuges and explicitly endorse grazing and haying for strictly economic purposes (Strassmann 1983). Because the National Wildlife Refuge System Administration Act had not been passed when these plans were written, they do not stipulate that economic uses must be compatible with the protection of wildlife. Some managers whose grazing and haying programs have not been updated might have listed species as positively affected by grazing or haying, even though demonstrative evidence was lacking, so as to stave off litigation. Others openly commented that overgrazing is destroying the wildlife value of their refuges and should be eliminated-but that political hurdles preclude or delay stocking cuts.

It is beyond the scope of this review to summarize the literature on the wildlife that managers agree is negatively affected by cattle grazing or haying. Such a summary would emphasize, however, the relative unimportance of the potential positive effects of special, carefully controlled grazing and haying programs on a few wildlife species compared to their harmful effects on the majority of wildlife species once the economic needs of permittees have been accommodated. An average of two federally listed and two state listed endangered and threatened species occur at each NWR with grazing or haying programs (Strassmann 1983). The effect of grazing and haying on these species is still poorly understood, and the FWS has not developed recovery plans for most of them. Threatened and endangered species for which harmful effects of cattle grazing have been documented include desert bighorn sheep (Ovis canadensis) (FWS 1981), desert tortoises (Gopherus agassizi) (Berry 1978), and the Lahontan cutthroat trout (Salmo clarkei henshawi) (FWS 1980c). Cattle have forced bighorn sheep out of former refuge habitat, trampled tortoises, and muddied trout streams.

\section{Livestock Effects on Aquatic and Riparian Habitats}

Livestock overgrazing is the most pervasive cause of the deterioration of riparian ecosystems on public lands (Carothers 1977, Knoppf and Cannon 1982). Rangelands close to streams and lakes are especially prone to overgrazing because cattle congregate in flat areas close to water (Van Vuren 1982). Cattle are sometimes thought to be the ecological equivalents of 
American bison (Bison americana), but bison distributed their grazing pressure more widely because they grazed steep slopes and areas distant from water (Van Vuren 1982). Bison were also nomadic, so their forage plants had more time to recover between uses.

The principal results of overgrazing of riparian zones include (a) loss of the streamside vegetation that shades the water and prevents high water temperatures and low levels of dissolved oxygen (Platts 1981, Rickard and Cushing 1982), and (b) trampling, which erodes streambanks and increases water turbidity, thereby lowering the amount of aquatic plant and animal food available to wildlife (Bue and others 1964). In the arid and semiarid West, riparian ecosystems potentially produce the greatest abundance and diversity of wildlife (Sharpe 1979, Platts 1978). Damage to riparian ecosystems through overgrazing therefore can cut wildlife production substantially.

Managers' responses report many cases of damage to wildlife habitats near to water. Specific examples include: soil compaction, bank sloughing, loss of riparian trees, and loss of nesting cover at Benton Lake NWR, Montana; loss of vegetative cover in former waterfowl and upland bird habitat at Bowdoin NWR, Montana; trampling of shorelines and wildlife watering and resting areas at Klamath Forest NWR, Oregon; trampling of stream banks, lake margins, and natural springs at Clear Lake NWR, California; erosion and deep rutting at the Alaska Maritime NWR, Arkansas; and increasing turbidity and siltation and the disappearance of lakeside vegetation at Mingo NWR, Missouri.

\section{Cattle Fences}

Thousands of kilometers of barbed wire fences have been built at NWRs to control where and when cattle graze. Refuges with grazing and haying programs reported a total of $5384 \mathrm{~km}$ of boundary fences and $3414 \mathrm{~km}$ of internal fences; 1126 additional $\mathrm{km}$ of fences are planned. The vast majority of these fences are designed exclusively for regulating cattle. For example, at the Sheldon Refuge, which provides important pronghorn habitat in Nevada, the FWS is adding $117 \mathrm{~km}$ of cattle fences to the $88 \mathrm{~km}$ that already exist (FWS 1980c).

Fences have killed big game-especially pronghorn antelope that try to crawl under barbed wires during their migrations (Wagner 1978, Braun and others 1978). Despite improvements in fence design, pronghorn mortality still happens-especially when snow piles up along fence lines. At Gray's Lake NWR in Idaho and Malheur NWR in Oregon, fences have entangled greater sandhill cranes and flightless young whooping cranes (Grus americana) (Braun and others 1978). Managers' survey responses show that in addition to paying the costs of fence construction in the interior of refuges, the FWS provided the labor for $1971 \mathrm{~km}$ and the materials for $2253 \mathrm{~km}$ of boundary fences in closed range. Construction of these fences by the FWS is a federal subsidy to ranchers because, by law, closed ranges are defined as areas where ranchers have the obligation to prevent their cattle from trespassing on adjacent lands.

\section{Emergency Haying}

During extreme drought years, when agricultural communities surrounding refuges are experiencing poor hay harvests, the FWS sometimes opens refuges to "emergency haying" for commercial purposes. This haying is additional to that which takes place under regular permits. Fiscal year 1980 was a drought year and emergency haying was widespread at the refuges of the prairie pothole states. Managers' survey responses indicate that the FWS issued 2739 permits for harvesting 7297 metric tons of emergency hay on 5152 ha.

Haying can be harmful to ground-nesting waterfowl and upland birds because it reduces the residual cover needed for nesting the next spring (CVWMA 1974). When haying takes place in the breeding season, ground-nesting birds are destroyed by mowers (Braun and others 1978). The conservation committee of the Wilson Ornithological Society (Braun and others 1978) concluded that if haying at refuges is permitted, then it should be delayed until sometime in August, when most birds would have fledged. The survey shows, however, that $83 \%$ of the refuges that permitted haying allowed it before 16 July.

\section{Permits}

During fiscal year 1980, the FWS issued 738 permits to private ranchers for grazing, 612 permits for haying (exclusive of "emergency haying"), and 42 permits for a combination of grazing and haying at NWRs (Table 6). Managers reported that 95,000 AUMs of cattle grazing was permitted because grazing was a traditional use-although a federal District Court judge has ruled that whether a use is traditional has no influence on its permissibility (Ruby Lake case: Defenders of Wildlife v. Andrus, 11 ERC 2098). The grazing permits had an average tenure of slightly over 1 year, but a 20-year tenure was reported for Simenof Island in the Alaska Maritime NWR (Strassmann 1983). Such tenures mean that decisions on stocking 
Table 6. Reported numbers of permits for cattle grazing and haying at refuges (from Strassmann 1983).

\begin{tabular}{lccc}
\hline & Total & $\begin{array}{c}\text { Mean } \\
\text { per refuge }\end{array}$ & $\begin{array}{c}\text { Maximum } \\
\text { per refuge }\end{array}$ \\
\hline $\begin{array}{l}\text { Number of } \\
\text { grazing permits }\end{array}$ & 738 & 6.05 & 88 \\
$\begin{array}{l}\text { Number of } \\
\text { haying permits }\end{array}$ & 612 & 4.98 & 98 \\
$\begin{array}{l}\text { Number of } \\
\text { combination } \\
\text { grazing/haying }\end{array}$ & & & \\
permits & 42 & 0.35 & 12 \\
\hline
\end{tabular}

intensities are made before the grazing season. Because rainfall is unpredictable and forage production consequently varies markedly from season to season and year to year (Stoddart and others 1975), advance decisions on the intensity and distribution of grazing are unlikely to be tailored appropriately to actual conditions. For these reasons "grazing as a wildlife management tool" is unlikely to work in practise-even in those cases when it could in theory.

\section{Prescribed Burning}

Native prairies at NWRs evolved with periodic wildlife as an important ecological factor. Protection against fire has caused the invasion of woody species and a reduction in wildlife food (Kirsch and Kruse 1973, Vogl 1974). Many refuges therefore have reintroduced controlled fires-a technique called prescribed burning.

Although refuges sometimes consider grazing a substitute for fire, grazing and burning differ in important respects. An occasional burn releases nutrients from dead vegetation and makes them available for uptake in new plant growth (Vogl 1974). Grazing gradually removes nutrients from grassland ecosystems as the forage is converted into beef and shipped away. Specifically, for each kilogram of choice grade beef from a whole carcass with bone (raw), $7.9 \mathrm{~g}$ of nitrogen, $1.1 \mathrm{~g}$ of phosphorus, and 0.55 $\mathrm{g}$ of potassium are lost to grassland ecosystems (calculated from data in Watt and Merrill 1963).

Burning, unlike grazing, is conducted over a short interval and is not reintroduced for several years. Grazing is seldom limited to one season-it spans two seasons or more at 88 of 104 refuges, and occurs annually (year after year) at 52 of them (Strassmann 1983). Such use patterns vastly exceed those that would be appropriate if grazing were used as a "wildlife management tool." For example, some refuges permit "crowd" grazing (heavy use for a brief period) in spring to reduce the growth of cool season grasses in native prairies. Unfortunately the grazing is often continued throughout the summer (Strassmann 1983) even though summer grazing is detrimental to wildlife production (Braun and others 1978). The pressure for excessive grazing is unavoidable because short grazing periods do not support cattle long enough to be economically advantageous to permittees. Overuse of prescribed burning could volatilize excessive quantities of nitrogen and reduce soil fertility (Parton and Risser 1980 ), but there is no political or economic incentive for overburning so this risk is negligible.

\section{Costs}

The total reported cost of administering cattle grazing and haying programs at $81 \%$ of the refuges allowing these activities was $\$ 919,740$ (19\% of the refuges did not answer the survey question on costs). According to the FWS the federal government earned $\$ 973,431$ from issuing refuge grazing and haying permits in FY 1980 (FWS 1980a). Superficially, therefore, it looks as though the FWS breaks even on grazing and haying. This is not the case, however, because (a) revenues go to the US Treasury rather than directly back into refuge programs like endangered species and migratory bird management, and (b) the cost of the degradation of wildlife habitat by grazing and haying is not accounted for.

In addition to draining funds, grazing and haying programs at some refuges are a drain on staff time. The most extreme example is the Charles M. Russell NWR, Montana, where refuge staff reported that $50 \%$ of refuge funds and $55 \%$ of refuge staff time go toward managing grazing and haying. The public pays dearly for these uses because according to the 1984 Draft EIS for the Charles M. Russell NWR, forage allocations under present management are "dominantly in favor of livestock" and "continue to depress habitat values for wildlife" (FWS 1984:67-68) (Figure 2).

The survey results show that the average fee charged to refuge ranchers per AUM of grazing was $\$ 4$ 44. Refuge grazing fees are considerably below fair market value. For example, at the Charles M. Russell NWR, Montana, grazing fees were \$1.80/AUM, while state fees in Montana were at least $\$ 3.74 / \mathrm{AUM}$, and private fees in Montana were at least $\$ 8.40$ /AUM (FWS 1980b). The average fee/ton of hay harvested at refuges was $\$ 6.90$, while the average price/ton of all hay on private lands in the USA was $\$ 70.90$ in 1980 (USDA 1981). Refuge grazing and haying fees are lower than fair market value partly because refuges overwhelmingly choose permittees by tradition, lot- 


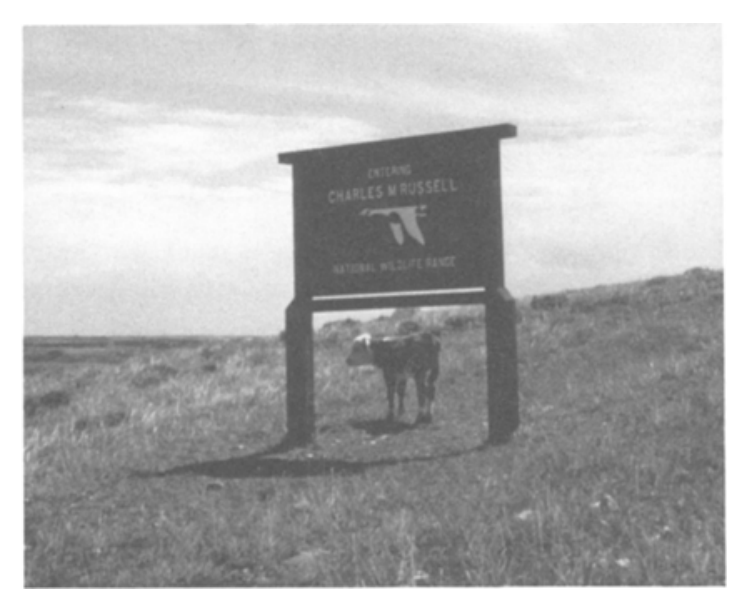

Figure 2. Entrance to the Charles M. Russell National Wildlife Refuge, Montana. (The refuge used to be a "range" and the sign has not yet been changed; photo by Hank Fischer.)

tery, and negotiated sales rather than by competitive bid (Strassmann 1983).

\section{Conclusion}

Data from various studies suggest that a few wildlife species may have the potential to benefit from cattle grazing or haying under particular circumstances but only when these programs are carefully controlled and tailored to wildlife habitat requirements. However, refuge grazing and haying programs primarily accommodate the economic needs of permittees rather than the ecological needs of wildlife. Thus, although in theory cattle grazing and haying can be wildlife management tools, as implemented they are tools that do more harm than good. This conclusion is strengthened when one considers that for the majority of wildlife species there are no data indicating that even controlled grazing can be beneficial, while numerous studies report that cattle grazing adversely affects these species.

Moreover, those wildlife species that do benefit from short-grass conditions could be equally well or better served by prescribed burning. Most important, NWRs are the nation's only lands dedicated above all to wildlife protection. They best fulfill their purpose when they emphasize the protection of habitats that are disappearing under other ownerships. Species preferring grazed or hayed lands have ample areas already available to them.

Federal subsidies to permittees make refuge grazing and haying permits attractive and create pressure for increased grazing. Thus, efforts to reduce stocking levels at refuges meet with formidable oppo- sition from ranchers. Since 1974 there have been a number of aborted initiatives by the FWS to counter the pressure and to reduce grazing except where it can demonstrably benefit wildlife (for example, Greenwalt 1978). None of these initiatives succeeded-probably because of the inherent conflicts between what is best for cattle production and what is best for wildlife production. From 1975 to 1980 , grazing increased from 354,589 to 374,849 AUMs (FWS 1976, Strassmann 1983). In 1983, FWS Director Jantzen ordered additional increases in AUMs. It is therefore unlikely that the FWS will implement stocking reductions on its own initiative. Instead, any reductions in refuge grazing and haying must derive from broad national support. Despite a federal court ruling that economic values may not be weighed against refuge purposes [50 CFR $25(11) \mathrm{b}]$, the future of cattle grazing and haying may depend on the value of refuges to present and future generations compared to their economic benefits for 1400 permittees.

\section{Acknowledgments}

I thank US Fish and Wildlife Service personnel—in particular, refuge managers--for their patient cooperation with my grassland management survey and assistance in the field. I also appreciate the helpful comments of the following individuals: $\mathrm{T}$. Cooper, $\mathrm{H}$. Damman, G. C. Eickwort, D. Fergusen, C. Fried, C. A. S. Hall, L. M. Kirsch, E. Knoder, C. D. Littlefield, B. S. Low, R. J. Mackie, D. Pimentel, P. Plaza, W. C. Reffalt, D. A. Sheiman, A. E. Smith, J. Wald, and M. Zorza.

\section{Literature Cited}

Berry, K. H. 1978. Livestock grazing and the desert tortoise. Transactions of the North American Wildiffe and Natural Resources Conference 43:505-519.

Bicak, T. K., R. L. Redmond, and D. A. Jenni. 1982. Effects of grazing on long-billed curlew (Numenius americanus) breeding behavior and ecology in southwestern Idaho. Pages 74-85 in J. M. Peek and P. D. Dalke (eds.), Wildlife-livestock relationships symposium: proceedings 10 . University of Idaho Forest, Wildlife, and Range Experiment Station, Moscow, Idaho.

Braun, C. E., K. W. Harmon, J. A. Jackson, and C. D. Littlefield. 1978. Management of national wildlife refuges in the US: its impacts on birds. Wilson Bulletin 90:309-321.

Brown, D. E. 1978. Grazing, grassland cover and gamebirds. Transactions of the North American Wildlife and Natural Resources Conference 43:477-485.

Bue, G., L. Blankenship, and W. H. Marshall. 1952. The relationship of grazing practices to waterfowl breeding popu- 
lations and production on stock ponds in western South Dakota. Transactions of the North American Wildlife and Natural Resources Conference 17:39-414.

Bue, I. G., H. G. Uhlig, and J. D. Smith. 1964. Stock ponds and dugouts. Pages 391-398 in J. P. Linduska (ed.), Waterfowl tomorrow. US Government Printing Office, Washington, DC.

Burgess, H. H., H. H. Prince, and D. L. Trauger. 1965. Blue-winged teal nesting success as related to land use. Joumal of Wildlife Management 29:89-95.

Capel, S. W. 1965. The relationship between grazing and predator activity in four types of waterfowl nesting cover. MA thesis, University of Missouri, Columbia, Missouri, 78 pp.

Carothers, S. W. 1977. Importance, preservation, and management of riparian habitats: an overview. In $\mathrm{R} . \mathrm{R}$ Johnson and D. A. Jones (eds.), Importance, preservation, and management of riparian habitat: a symposium. USDA Forest Service General Technical Report RM-43.

Clark, J. 1977. Effects of experimental management schemes on production and nesting ecology of ducks at Malheur National Wildlife Refuge. MS thesis, Department of Fish and Wildlife, Oregon State University, Corvallis, Oregon, 66 pp.

CVWMA. 1974. Habitat requirements for ground-nesting waterfowl and effect of grazing and other cover removal activities on nesting. Creston Valley Wildlife Management Authority, Box 640, Creston, British Columbia, Canada.

Deubbert, H. F., and J. T. Lokemoen. 1977. Upland nesting of American bitterns, marsh hawks, and short-eared owls. Prairie Naturalist 9:33-40.

Ellisor, J. E. 1969. Mobility of white-tailed deer in south Texas. Journal of Wildlife Management 33:221-222.

FWS. 1976. Final environmental statement on the operation of the National Wildlife Refuge system. US Fish and Wildlife Service, Washington, DC.

FWS. 1980a. Land use and economic benefits. FY 1980. US Fish and Wildlife Service, Washington, DC.

FWS. 1980b. Annual narrative report: Aransas National Wildlife Refuge. Austwell, Texas.

FWS. 1980c. Final environmental impact statement, Sheldon National Wildlife Refuge. US Fish and Wildlife Service, Portland, Oregon.

FWS. 1981. Kofa National Wildlife Refuge final environmental impact statement: proposal to eliminate cattle and wild burros on Kofa National Wildlife Refuge. US Fish and Wildlife Service, Albuquerque, New Mexico, 108 pp.

FWS. 1982. Refuge manual (6 RM 9.1). US Fish and Wildlife Service, Washington, DC.

FWS. 1984. Charles M. Russell National Wildlife Refuge draft environmental impact statement. US Fish and Wildlife Service, Denver, Colorado.

Greenwalt, L. A. 1978. The National Wildlife Refuge system. Pages 399-412 in H. P. Brokaw (ed.), Wildlife and America. Council on Environmental Quality, US Government Printing Office, Washington, DC.

Hood, R. E., and J. M. Inglis. 1974. Behavioral responses of white-tailed deer to intensive ranching operations. Journal of Wildlife Management 38:488-498.

Holechek, J. L., R. Valdez, S. D. Schemnitz, R. D. Pieper, and C. A. Davis. 1982. Manipulation of grazing to improve or maintain wildlife habitat. Wildlife Society Bulletin 10:204210.

Jahn, L. R., and R. A. Hunt. 1964. Duck and coot ecology and management in Wisconsin. Wisconsin Department of Conservation Technical Bulletin 33, 212 pp.

Jantzen, R. A. 1983. Memorandum: Guidelines for implementing compatible public and economic use expansion on National Wildlife Refuges. Dated 1 April 1983. US Fish and Wildlife Service, Washington, DC.

Kessler, W. B., and R. P. Bosch. 1982. Sharp-tailed grouse and range management practices in western rangelands. Pages 133-146 in J. M. Peek and P. D. Dalke (eds.), Wildlife-livestock relationships symposium: proceedings 10 . University of Idaho Forest, Wildlife and Range Experiment Station, Moscow, Idaho.

Kirsch, L. M. 1969. Waterfowl production in relation to grazing. Journal of Wildlife Management 33:821-828.

Kirsch, L. M. 1974. Habitat management considerations for prairie chickens. Wildlife Society Bulletin 2:124-129.

Kirsch, L. M., H. F. Deubbert, and A. D. Kruse. 1978. Grazing and haying effects on habitats of upland nesting birds. Transactions of the North American Wildlife and Natural Resources Conference 43:486-497.

Kirsch, L. M., and K. F. Higgins. 1976. Upland sandpiper nesting and management in North Dakota. Wildife Society Bulletin 4:16-20.

Kirsch, L. M., and A. D. Kruse. 1973. Prairie fires and wildlife. Proceedings of the Tall Timbers Fire Ecological Conference 12:289-303.

Klimstra, W. D., and J. L. Roseberry. 1975. Nesting ecology of the bobwhite in southern Illinois. Wildlife Monographs 41, $37 \mathrm{pp}$.

Knoppf, F. L., and R. W. Cannon. 1982. Structural resilience of a willow riparian community to changes in grazing practices. Pages 198-207 in J. M. Peak and P. D. Dalke (eds.), Wildlife-livestock relationships symposium: proceedings 10. University of Idaho Forest, Wildlife and Range Experiment Station, Moscow, Idaho.

Littlefield, C. D., R. S. Johnstone, and S. P. Thompson. 1979. Winter hunting activity of marsh and rough-legged hawks as related to land use on the Malheur National Wildlife Refuge, Oregon. Paper presented at the Raptor Research Annual Meeting, 8-12 November 1979, Davis, California.

Mackie, R. J. 1978. Impacts of livestock grazing on wild ungulates. Transactions of the North American Wildlife and Natural Resources Conference 43:462-476.

McMahan, C. A., and C. W. Ramsey. 1965. Response of deer and livestock to controlled grazing in Central Texas. Journal of Range Management 18:1-7.

McNay, M. E., and B. W. O'Gara. 1982. Cattle-pronghorn interactions during the fawning season in northwestern Nevada. Pages 593-606 in J. M. Peek and P. D. Dalke (eds.), Wildlife-livestock relationships symposium: proceedings 
10. University of Idaho Forest, Wildlife and Range Experiment Station, Moscow, Idaho.

NWR Task Force. 1979. Recommendations. Page 9 in Final recommendations on the management of the National Wildlife Refuge system. US Fish and Wildlife Service, Washington, DC.

Parton, W. J., and P. G. Risser. 1980. Impact of management practices on the tallgrass prairie. Oecologia (Berlin) 46:223234.

Platts, W. S. 1978. Livestock interactions with fish and aquatic environments: problems in evaluation. Transactions of the North American Wildlife Natural Resources Conference 43:498504.

Platts, W. S. 1981. Streamside management to protect bankchannel stability and aquatic life. Pages $245-255$ in D. M. Baumgartner (ed.), Interior west watershed management: proceedings of a symposium. Cooperative Extension, Washington State University, Pullman, Washington.

Rickard, W. H., and C.E. Cushing. 1982. Recovery of streamside woody vegetation after exclusion of livestock grazing. Journal of Range Management 35:360-361.

Salyer, J. W. 1962. Effects of drought and land use on prairie nesting ducks. North American Wildlife and Natural Resources Conference 27:69-79.

Sharpe, M. 1979. Rangeland condition. Pages 29-33 in Rangeland policies for the future: proceedings of a symposium, 28-31 January, 1979, Tucson, Arizona. USDAUSDI, CEQ. US Government Printing Office, Washington, DC, GTR WO-17.

Smith, R. J. 1977. Conclusions. In Proceedings of a seminar on improving fish and wildlife benefits in range manage- ment. Biological Services Program, US Fish and Wildlife Service, Washington, DC, FWS OBS-77/1.

Stoddart, L. A., T. W. Box, and A. R. Smith. 1975. Range management, 3rd edn. McGraw-Hill, New York, New York, 532 pp.

Strassmann, B. I. 1983. Grazing programs on federal rangelands and refuges: consequences for wildlife, beef production, and fossil fuel use. MS thesis, Cornell University, Ithaca, New York, 167 pp.

USDA. 1981. Agricultural statistics. Statistical Reporting Service, US Government Printing Office, Washington, DC, $981 \mathrm{pp}$.

Van Vuren, D. 1982. Comparative ecology of bison and cattle in the Henry Mountains, Utah. Pages 449-457 in J. M. Peek and P. D. Dalke (eds.), Wildlife-livestock relationships symposium: proceedings 10. University of Idaho Forest, Wildlife and Range Experiment Station, Moscow, Idaho.

Vogl, R. J. 1974. Effects of fire on grasslands. Pages 139-194 in T. T. Kozlowske and C. E. Ahlgren (eds.), Fire and ecosystems. Academic Press, New York, New York.

Wagner, F. H. 1978. Livestock grazing and the livestock industry. Pages 121-145 in H. P. Brokaw (ed.), Wildlife and America. Council on Environmental Quality, US Government Printing Office, Washington, DC.

Watt, B. K., and A. L. Merrill. 1963. Composition of foods. USDA, Agricultural Research Service, Agricultural Handbook no. 8. US Government Printing Office, Washington, DC, 190 pp.

Weller, M. W., B. H. Wingfield, and J. P. Low. 1958. Effects of habitat deterioration on bird populations of a small Utah marsh. Condor 60:220-226. 